\title{
Ni libre ni asalariado: una experiencia de investigación colaborativa para fomentar la antropología visual
}

\section{Neither free nor wage earner. A collaborative research experience to promote visual anthropology}

\author{
Por: María Ochoa Sierra', José Leonardo Cataño² \& César Augusto Tapias Hernández ${ }^{3}$ \\ 1. Socióloga, magíster en ciencia política. Investigadora y Coordinadora de Posgrados y Extensión Instituto de Estudios Políticos de la Universidad de Antioquia. \\ Contacto: maria.ochoas@udea.edu.co \\ 2. Antropólogo. Estudiante de maestría en Economía Aplicada, Universidad Eafit. Contacto: joseleonardocatano@gmail.com \\ 3. Sociólogo, magister en Antropología y estudiante del doctorado en Comunicación de la Universidad del Norte, becario Colciencias. \\ Contacto: cesartapias1@gmail.com
}

\section{OPEN ACCESS}

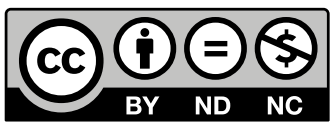

Copyright: @ 2018 Ochoa Sierra, M, Cataño, J, L \& Tapias Hernández, C, A. La Revista El Ágora USB proporciona acceso abierto a todos sus contenidos bajo los términos de la licencia creative commons Atribución-NoComercial-SinDerivar 4.0 Internacional (CC BY-NC-ND 4.0)

Tipo de artículo: Investigación. Recibido: diciembre de 2016

Revisado: mayo de 2017

Aceptado: junio de 2017

doi: http://dx.doi.org/10.21500/16578031.3443

Citar así: Ochoa Sierra, M., Cataño, J., \& Tapias Hernández, C. A. (2018). Ni libre ni asalariado: una experiencia de investigación colaborativa para fomentar la antropología visual. El Ágora USB, 18(1), 89-113. doi:http://dx.doi. org/10.21500/16578031.3443

\section{Resumen}

La antropología visual, como metodología de investigación, es válida en las ciencias sociales. Se destaca así, en este método, el proceso participativo y colaborativo devenido de la experiencia de trabajo etnográfico colectivo y audiovisual. Se desarrolla esta propuesta metodológica en el estudio de un caso concreto: los "pileros" afrodescendientes; obreros que trabajan en la construcción de pilas de cimentación, un oficio racializado, realizado por afrodescendientes de la ciudad de Medellín.

Palabras clave. Antropología visual; representación; etnografía; oficios racializados; racismo estructural; afrodescendientes; pilas; caisson; pilería.

\section{Abstract}

Visual anthropology, as a research methodology, is valid in the social sciences. In this method, which became the experience of the collective and audiovisual ethnographic work, the participatory and collaborative process is highlighted. This methodological proposal is developed in a concrete case study: the Afro-descendant "pileros;" who are workers who work in the construction of caissons. It is a racialized trade, carried out by people of African descent in the city of Medellín.

Key words: Visual Anthropology; Ethnographic Representation; Racialized Trades; Structural Racism; Afro-descendants; Piles; Caisson; "Pilería." 
"En consecuencia, los dominantes se llamaron a sí mismos blancos"

Quijano, Anibal.

Colonialidad del poder, eurocentrismo y América Latina.

"(...) y luego el sentimiento y la conciencia de un espacio simbólico para la vivencia de las memorias históricas, que responda la pregunta, i¿de dónde venimos?!.

Nina S. De Friedemann.

La Saga del Negro.

\section{Introducción}

Una caracterización de la población afrodescendiente en la ciudad de Medellín, elaborada por el movimiento social negro y la administración municipal, permite identificar que uno de cada diez habitantes de la ciudad de Medellín se percibe como Negro (a), moreno(a), Mulato(a), Raizal, Chocoano(a), Urabaense, de la región pacífico, San Basilio o afro colombiano(a). A su vez, identifica que los barrios en los que habita mayoritariamente esta población son Aranjuez, La Candelaria, Manrique, Robledo, Villa Hermosa, La América, San Javier y en el Corregimiento de San Antonio de Prado. El 62,4\% de la población afro recibe un salario mínimo o inferior, el 24\% entre 1 y 2 salarios mínimos y el 86,4\% de la población gana 2 salarios mínimos o menos. Allí también se destaca la labor de los llamados pileros, como ocupación masculina significativa en la construcción de los cimientos de las principales estructuras de la ciudad. Además muestra que en las labores de construcción de unidades residenciales, centros comerciales y equipamientos urbanísticos la participación de la población masculina afrodescendiente en las labores de construcción corresponde al $40.9 \%$ del total de trabajadores, en edades entre los 15 y 30 años. Los trabajadores afrodescendientes reconocidos como pileros representan el $66.7 \%$ de la economía de construcción municipal, y la figura de contratación es verbal por obra o labor contratada. De la población masculina afro habitante de Medellín, el 96.7\% solo se dedica al trabajo de la construcción mientras que un $66.2 \%$ de esos trabajadores, desea cambiar de trabajo (Alcaldía de Medellín y Convivamos, 2011).

Con el fin de narrar las vidas detrás de esas cifras y establecer una descripción sobre este oficio, un grupo de ocho investigadores de la Corporación Pasolini en Medellín conformado por dos antropólogos, dos estudiantes de antropología, dos sociólogos, una comunicadora y dos realizadoras audiovisuales (una de ellas estudiante de antropología), presentamos un proyecto al Instituto Colombiano de Antropología e Historia (ICANH) y ganamos la beca Nina S. De Friedman de antropología visual en el año 2014. Lo que aquí se relata hace parte de ese proyecto y quiere ser una reflexión metodológica de un ejercicio colaborativo y de esta labor que además es poco conocida. Esto en parte porque sorprende que pese a la importancia de este oficio y a su racialización evidente, no haya estudios sobre los afros en la construcción de pilas de cimentación; se encontraron múltiples referencias en torno a los afrodescendientes en Colombia (Restrepo \& Rojas, 2008) pero muy pocas asociadas al oficio de los pileros (algunas referencias en la caracterización citada, así como unas fotografías de pileros en la misma institución, en el concurso los trabajos y los días de 2011 (Ceballos Montoya, 2011) y un artículo de prensa (Reinoso Rodríguez, 2014)). 
La antropología visual supone el reto básico que también comporta la etnografía: la comprensión reflexiva de otras formas de conocimiento, simbolización y significación, más que preguntando por ellas observándolas. "De tal suerte, se intentaría orientarse hacia la comprensión de los fenómenos abordados, no sólo hacia una mera descripción de los mismos. En este punto Ruby va un poco más lejos al asegurar que el objetivo fundamental del filme antropológico debe ser comunicar conocimiento antropológico y no concebir algo que la industria pueda llamar una buena película (2000: 38-39). Con ello se buscaría el desarrollo y la estructuración de una base teórica firme para la producción, no de sofisticar el efectismo de determinados formatos de presentación (Ruby, 2000: 23)" (Ruby, 2000 citado en Grau, 2012; p. 164).

En este caso, insertarse en el mundo de los pileros, hombres, en su mayoría afro, que cavan en lo profundo de la tierra para construir las bases de grandes infraestructuras implicó acercarse a un oficio poco conocido y explorado por los investigadores sociales, incluso aquellos que han trabajado con población afrodescendiente. Las preguntas con las que nos acercamos a este tema fueron ¿Cuánto ganan los pileros?, ¿Cómo son las formas de contratación?, ¿Les son vulnerados algunos derechos laborales?, ¿Las relaciones laborales Están atravesadas por formas de poder que derivan en discriminación y racismo?, ¿Por qué saben los hombres afro excavar en las profundidades?, ¿Qué relación existe entre la minería y la pilería?, ¿Por qué la mayoría de los hombres pileros viene de zonas del litoral pacífico? Estas fueron algunas de las preguntas que motivaron la realización del documental y que se resolvieron parcialmente en él, algunas quedarán detalladas en este artículo, otras requerirán ver el documental (Tapias, 2016) para ser mejor exploradas, y otras no pudieron desarrollarse plenamente en la investigación y requerirán futuras indagaciones.

En este artículo se hará una descripción del oficio de acuerdo a las narraciones de los pileros y de lo observado en trabajo de campo, posteriormente se propicia una reflexión antropológica de lo encontrado y finalmente se narra el proceso metodológico haciendo énfasis en la importancia de un enfoque colaborativo.

\section{Semblanza de un pilero}

Don Wilson Mosquera tiene 57 años, lleva diez años en el sector de la construcción y antes había trabajado en educación. Nació en Itsmina, Chocó y se graduó como bachiller técnico en producción textil y detrás de los paisanos fue que llegó primero a Medellín, estuvo unos poquitos años intentando entrar en el negocio, pero mejor se fue para el Guaviare también detrás de paisanos y allí participó en un proceso de alfabetización para adultos y también acompañó a jóvenes en los primeros años escolares. Quiso seguir estudiando en la Universidad, pero por algunos problemas que se le presentaron todo cambió y de regreso en Medellín lo primero que tuvo oportunidad de hacer para ganarse algo de dinero y mantener su familia, fue la construcción "Fue un cambio muy duro". Como profesor, a las 11 de la mañana ya había cumplido su jornada, como obrero a las 11 de la mañana, apenas llevaba media jornada. Ahora vive en el barrio Manrique, tiene tres hijos, dos de ellos en la Universidad, una estudia lenguas extranjeras, y las otras dos educaciones físicas "eso es lo que ellos querían y los he apoyado" recuerda que cuando tenía la edad de sus hijos también tuvo apoyo, pero no suficientes oportunidades "en aquella época ser un bachiller técnico era lo máximo."

Empezó tirando pico y pala y fue de a poco que pudo ascender. Hoy trabaja en la parte de la pilería, lo que más le atrae es la construcción de las Estructuras. Dice que su trabajo es muy importante, de lo que se trata de construir las bases o mejor el esqueleto de la construcción. Es un trabajo lleno de seguros y pólizas y una constante revisión para garantizar que se cumpla con la labor "si lo hiciera mal puedo perder todo mi patrimonio". Desde temprano entendió que el pilero puede ganar dinero si su trabajo rinde, al contrario, 
puede perder si no cumple con los programas. Nos dice que en la obra hay un tablero en donde pueden verse las diferentes actividades programadas con gente, recursos y tiempo, y donde también hay una especie de evaluación laboral. Por eso no puede buscarse otro trabajo de medio tiempo, a veces para cumplir con los programas trasnocha o se extienden sus jornadas. En cada obra es contratado por su patrón, un hombre con conexiones en diferentes frentes de construcción en la ciudad y para quien siempre es el encargado de coordinar a otros excavadores como él. Define su oficio como excavador, pero nos deja ver cómo en este oficio es importante, no sólo tener pulmones y fuerza, sino contar con el compañero. Llega a las obras por un patrón que lo conoce, y lo contrata, pero él siempre llega con su compañero. Los buenos compañeros deben conversar y entenderse muy bien, esta es una de las formas de evitar accidentes. Cuenta de la muerte de un chico muy joven a quien una piedra le cayó sobre el pecho y lo mató. No tenía experiencia y su compañero se confió (pensar en la imagen del hueco, y afuera, ver la fuerza del compañero sacando el material excavado por el de abajo, con la ayuda de una gran manivela). Parece que aunque es un oficio peligroso, la experiencia y el compañerismo son elementos importantes para sobrevivir; aunque "es un trabajo que pueda ser cualquiera". Don Wilson dice que la mayoría de hombres negros en el negocio están ahí por la capacidad pulmonar (pensé ¿quién le habrá dicho eso; quién podría confirmar esto?) y tocándose la piel dice que también hay mulatos y no negros excavando

"pero son pocos, y están ahí porque son verracos". Don Wilson dice que conoce casi todos los pileros de la ciudad, ya que en algún momento estuvieron a su cargo, incluido don Aurelicio. Ha trabajado construyendo centros comerciales como El Tesoro y Florida, hay años en donde puede haber sólo una obra, o hasta tres, en el centro comercial Florida estuvo 18 meses (Notas de campo, 2014).

\section{El Oficio}

Yo me llamo Aurelicio palacio nací el 30 de junio de 1965 en el departamento de Chocó desde la edad de 12 años, me levanté trabajando la mina hasta los 18 años, de ahí fue que me vine para acá pa`Medellín me metí en el cuento de las pilas. El 99\% de las pilas la hace las razas negras, porque nosotros los afros venimos de una cultura de la minería y también por la falta de oportunidad, es un trabajo que nosotros lo hacemos brutalmente, que es la parte, la parte sucia, es un oficio difícil, duro, pero eso es lo que nosotros sabemos hacer y en eso es en lo que nosotros nos debatimos y ahí es donde nos ganamos la vida (...) La vía que conduce de aquí Medellín hacia el Chocó, se nos mató 2 compañeros: el finado Hernán y Óscar Becerra. Óscar becerra es el contratista y el finado Hernán era un compañero de trabajo, el trabajador bajó, llamo al contratista para que bajara a verificar porque buscaba acortársele la respiración, y cuando bajó el contratista, ya estaba el compañero allá tirado y trató de auxiliarlo a él, de amarrarlo y en ese momento también él quedó el allá (...) Pues las pilas es un negocio que nosotros las hacemos, pero siempre hay un contratista que contrata con la empresa. Ese contratista le contrata el ingeniero y nos pagan por metro unitario, por decir hago una pila 1-20 y lo están pagando en este momento a 50.000 otros los pagan a 55.000, una pila de 1-50 la pagan por ahí a 60.000 a 70.000 pesos, también nos pagan lo que es la cuestión de las piedras, si es una piedra grande por decir algo 5000 si es pequeña valen a 3000 pesos, todo eso son cosas que uno ya las arregla con el ingeniero o con el contratista (Aurelicio Palacios, Entrevista para documental, 2014).

Mi nombre es Néstor Arboleda, vengo de Itsmina Chocó, donde allá se trabaja mucho la minería, la agricultura y la pesca también se ve mucho, y llegue aquí a Medellín hace 22 años, donde empecé a trabajar la construcción. Este trabajo de las pilas, que es el que nosotros hacemos, este trabajo es peligroso, antes de levantarme de la cama le pido a Dios que me vaya muy bien, hay ocasiones 
de momentos amargos, pero hay otros momentos muy buenos y ahí he podido sostener la familia, y aquí en Medellín he conformado un grupo de vallenato, donde me toca componer, cantar y tener buena comprensión con los amigos, sí una buena amistad. Si, y así sobrevivimos, trabajando en construcción, cantando cuando nos contratan con el grupo vallenato. Sí, han sido unos sueños porque desde pequeño yo quise ser cantante (Néstor Arbolea, Entrevista para documental, 2014). Yo trabajé en esta obra fue como en el 2000, donde nos tocó hacer 20 pilas allí, el terreno era muy inestable, se bajaron a 12 metros, hubieron pilas ahí que se llevaron hasta 200 bultos de cemento, porque hoy la marcaba uno de 1-20 y al otro día amanecía de 3 metros, allá los compañeros siempre Vivían pendiente de los otros para que no se fueran a tirar abajo, esto fue una experiencia muy amarga (...) Trabajar aquí en cambio fue muy bueno porque la plata se vio, el terreno fue más estable y menos trabajo pasábamos para construir las pilas, al contrario del otro edificio, más duro allá y la plata la detenían, en cambio aquí sí se vio el dinero y estas pilas bajaron 10 metros, esto fue construido en el 2003. El ingeniero que hizo esta otra construcción aquí hizo un buen equipo de pileros, hicimos este edificio, el que sigue allá en el fondo, otro en Pilarica, y cada vez que le sale trabajo al hombre ahí mismo nos contrata y nosotros nos sentimos muy a gusto con el señor. Este edificio quedó en un buen terreno yo soy testigo, yo fui uno de los pileros que metió la barra aquí con fuerza y con ganas (Néstor Arboleda, Entrevista para documental, 2014).

El oficio de los pileros descrito por todos los entrevistados como un oficio fuerte y riesgoso, consiste en la construcción de estructuras de cimentación para grandes obras que por su peso o por la relativa inestabilidad del terreno requieren de excavaciones profundas en las que se enclavan las estructuras que después verán la luz y superarán por lo general la altura de la pila o caisson (su nombre en francés). Una pila se hace de la siguiente manera: para empezar se debe trazar el diámetro del círculo que excavará el pilero con la barra y la pala para lograr profundidad dependiendo de la necesidad de cada obra (algunas pueden llegar hasta los 25 metros). También deben proteger la pila con cemento para evitar que ceda, ya que de las pilas depende la estabilidad de una edificación, de esta manera se van construyendo unos anillos gigantescos con estructuras de hierro, que se bacean en cemento para protegerlos. Cuando hay agua en la profundidad del hoyo, debe bombearse y los residuos son extraídos por medio de un balde halado en un molinete que manipula manualmente uno de los pileros.

Para este oficio los pileros se organizan en parejas homogéneas (de estatura o peso similar): uno está arriba y protege al compañero y otro está abajo y excava el hoyo, destruye las piedras o drena el agua cuando es necesario. Quien está arriba se encarga de subir con el molinete y a través de una manila, el material que su compañero ha estado escavando, y de subirlo a él en caso de haber peligro o cuando haya terminado. El balde tiene guías y el molinete un dispositivo de frenado.

Yo trabajo en esto en primer aspecto porque no tengo más ingreso económico, pero como te digo yo tengo mi familia, mi mujer, tres hijos, yo pago arriendo y yo ganándome un mínimo no me alcanza para sostener la familia, en cambio con esto me da para el sustento de la familia. En estos momentos estoy trabajando por administración con la empresa, pero generalmente trabajo al contrato porque como te digo al contrato por ahí por lo menos el $80 \%$ nos va mucho mejor que trabajando por administración, porque uno al contrato depende de lo que uno se hace pero hay veces que a uno le va mucho mejor, o tres quincenas se hace millón y medio, millón doscientos hasta millón ochocientos por quincena, en cambio trabajando por administración nunca le van a pagar esa plata a uno (...) En estos momentos está así oscuro porque la norma dice que después de siete metros es la iluminación, pero ustedes acá no alcanzan a ver, pero yo allá puedo ver; allá trabajamos con unos compresores, trabajamos con la barra, con la pala y pica, esas cuatro herramientas son con las que 
trabajamos la pila, cuando tiene demasiada roca sólida utilizamos lo que es el ánfora, el indugel pa' voladura. Primero que todo la norma dice que después de uno con cincuenta debe uno usar arnete que ya es trabajo en altura, después de uno cincuenta yo me coloco el arnete, inspecciono el área de trabajo y ya le digo al compañero que está ahí. El permiso de altura, todos los días hay que firmarlo antes de ingresar, esa es una norma y ya después que firmemos el permiso de altura con el siso (Técnico en seguridad industrial y salud ocupacional (S.I.S.O)). aquí presente, él nos avala que ya podemos entrar a la pila, antes de eso no podemos ingresar a la pila. Ahora inspeccionamos el área, el arnete, el casco, si vamos a trabajar con esa máquina (taladro percutor) tenemos que colocarnos los tapa oídos, tenemos que utilizar la guaya porque ya no está permitida la Manila como esa si no ésta guaya, ese mosquetón es automático, el molinete que esté en buen estado, utilizamos el arrastrador, un freno que si por algún motivo el socio me suelta automáticamente me frena, tiene esta linga, esta linga está conectada acá atrás, si yo me freno esto me ancla y esos son los primeros pasos para iniciar a la pila. Ya después de que todo eso esté inspeccionado ahora sí le digo al socio que está allá, me engancho de este mosquetón, ya él le pide ayuda a un auxiliar pa podernos bajar dos personas, ahora sí este es el proceso, me anclo y ya (baja hacia la pila ayudado por su compañero). (Edison Palacios, Entrevista en obra, 2014).

Imagen 1. Oficio de la pilería, pareja de pileros y molinete (2014)

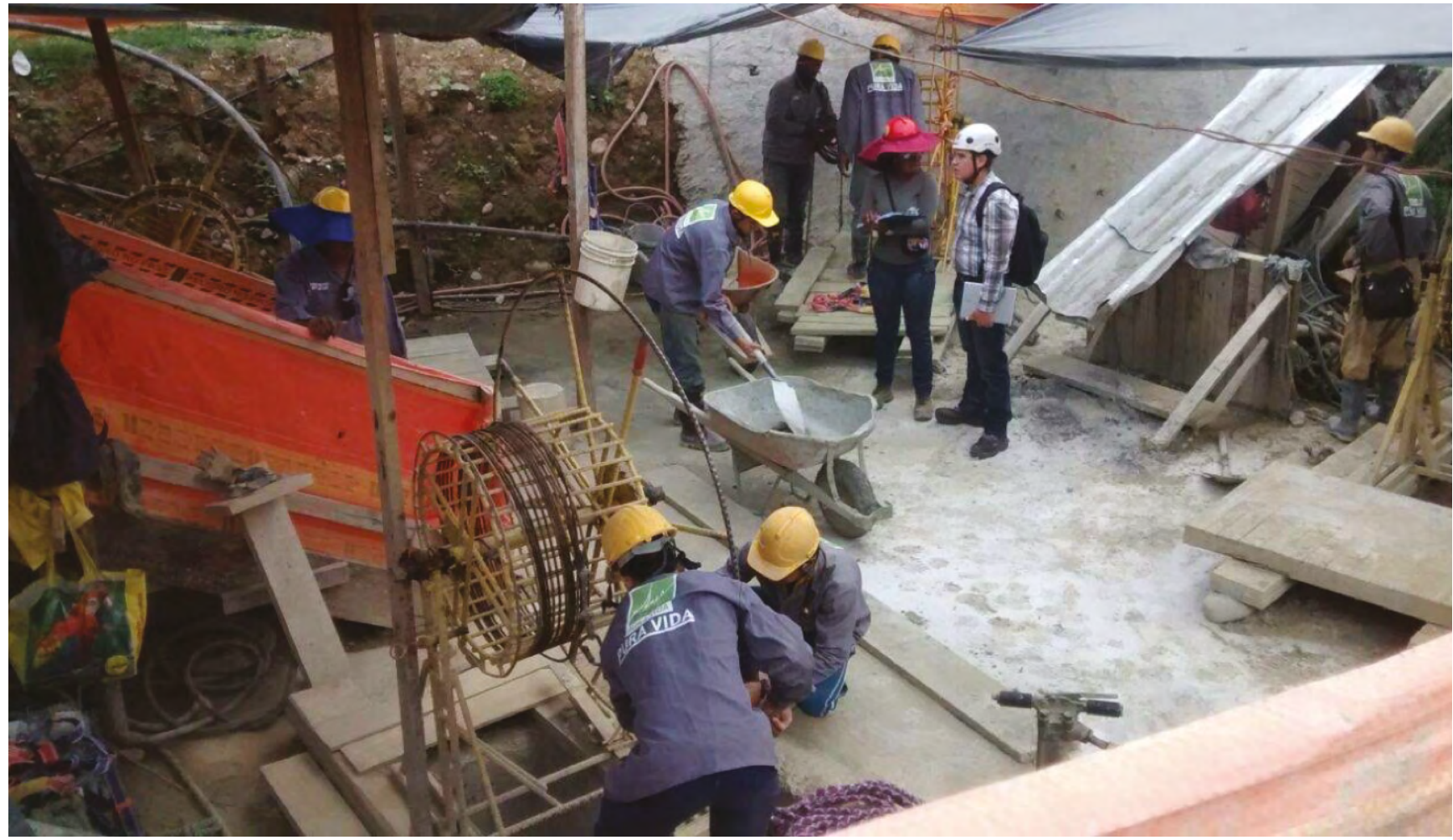

Fuente propia

Este oficio es peligroso y por eso quienes lo desempeñan deben respetar y conocer las normas de seguridad, que pasan por usar casco, arnés, una cuerda con un amarre especial que llaman línea de vida y que es controlada desde la superficie, pero sobre todo, elegir bien a su compañero. Se elige por afinidad, porque se destaque como buen 
trabajador y especialmente por la confianza que le pueda brindar a su pareja pues velará por él en todo momento. Las historias de accidentes se remiten a descuido de la pareja, desconocimiento del oficio o también a la negligencia de algunos ingenieros que por la premura del tiempo, exponen a los trabajadores (Notas de campo, 2014). Por lo anterior, los pileros valoran la experiencia en el oficio, y es motivo de crítica que los cursos de altura que deben tomar (y pagar) para ser contratados, sean ofrecidos por personas que no han trabajado en la construcción.

"Don Luis: y yo como compañero suyo le tengo que marcar la batuta ahí, si ud. está abajo y me están haciendo un trabajo a menos de dos metros iyo eso no lo acepto! y si lo van a hacer yo lo subo a usted. Es que a mí no me lo tiene que cuidar otro a usted, yo lo tengo que cuidar a usted. Néstor: es que la experiencia y el conocimiento en pila no quiere decir que hay que marcar las dos (pilas) ahí, siempre hay que dejar una pila por medio.

Néstor: se bacía esa y luego se hace la otra, por eso yo donde voy a trabajar siempre y cuando veo una retro cerca a una pila "ey pare ahí hermano, sáqueme al pilero"

Don Luis: eso! Es que así el ingeniero me diga, tiene que trabajar ahí y él haciendo su trabajo ahí cerca, yo no se los acepto y si lo hace él que sea con su compañero, porque yo no arriesgo a mi compañero de trabajo

Javier: ese fue el único día que he tenido la muerte cerquita, que fue ese día y otro día en Girardota, también habían dejado una pila, los muchachos se fueron y la dejaron ahí una semana y a los ocho días fui yo por allá a mirar, la secamos, eso estaba caído totalmente, sobre excavado. Entonces me dijo el patrón: "hay que limpiar eso y miremos como la vamos a aliviar" me le pegué a limpiar ese pantano, terminé como a las dos de la tarde de limpiar y le dijo: "ya limpié eso, pero eso está muy ancho eso no se puede vaciar" y dijo: "no eso hay que vaciarlo"

$* * *$

Néstor: y ahora con el proceso que hay que hacer para uno trabajar pila, ya tiene que hacerse el curso de altura, eso le dura un año y eso no le enseña a uno cómo trabajar pila y tiene que hacer ese curso de altura.

Javier: otra cosa, los manes que le dan a uno el curso de altura son personas que dan eso, o sea, eso lo sacó el gobierno como por generar empleo porque esa gente no sabe lo que nosotros hacemos en el trabajo de nosotros, ellos no saben, ellos dan eso ya como por cumplir.

Don Luis (mayor): es que ese curso de altura es lo mismo hacia abajo, pero la cosa es que es hacia arriba... de eso lo único que le sirve a uno es la cosa esa de guía de vida, un freno que le sirve a uno, se amarra acá y tiene un freno y se amarra a la cuerda de vida y ya queda como ponerle cuando ud. se soltó.

Néstor: y ahora viene otro proceso que todos los que trabajamos en construcción tenemos que hacer un curso en el Sena, no lo han aprobado, pero ya está que sale. El curso de altura vale 160 mil pesos y el que trabaja pila y no tiene esa platica no le dan el trabajo de pila (Conversación, Grupo focal, 27 abril de 2014).

Los pileros sienten que tienen un conocimiento que por su carácter empírico ha sido desconocido por los ingenieros y por las entidades que establecen los parámetros de contratación, así como por las que se encargan de la formación. El saber científico, experto, se posiciona como superior al saber que han acumulado los pileros a través de la elaboración del oficio y que trasmiten fuera de la educación formal, tal y como se producen otro tipo de aprendizajes asociados a disposiciones corporales y formas de hacer.

Néstor es enfático, por ejemplo, en que si bien él trabajó en el edifico Space, aquel que colapsó en Medellín el viernes 11 de octubre de 2013, él había alertado al ingeniero sobre la inestabilidad del terreno en relación con la profundidad de las pilas, pero el ingeniero ignoró su comentario (El Tiempo, 2014). 


\section{Estereotipos y racialización de los oficios}

En el proceso de duración de la elaboración de la investigación encontramos diversos estereotipos que enfrentan los pileros en tanto población marginalizada en Colombia, y como actores en el mundo de la construcción. Trabajaremos alrededor del estereotipo asociado a su labor: los afro hacen más rápido y mejor este trabajo porque debido a sus capacidades "biológicas" resisten más en las profundidades de la tierra y debajo del agua; son hombres problemáticos para trabajar porque conocen la normatividad y exigen sus derechos (Notas de campo, 2014).

Normalmente la población que hace este tipo de trabajo es de origen chocoano, y no nos podemos olvidar que el trabajo que ellos desempeñan en esas regiones es minería, y la minería tiene que ver también con socavones y excavaciones a profundidad, bajo tierra donde ellos están encontrando el sustento y el recurso. Entonces ellos vienen como con ese digamos ADN impreso en su sangre, están adaptados a un clima tropical húmedo, que es el mismo que se siente pues en la excavación bajo tierra, es un trabajo pesado y todos sabemos pues que la raza de color tiene esa capacidad de desarrollar un trabajo fuerte y pesado como es el de las pilas, es un trabajo riesgoso ellos también son muy aventurados, en cambio los que vivimos en la región andina somos un poco más temerosos, un poco más respetuosos de enfrentarnos a ese tipo de actividades, entonces por eso no es tan común que el denominado blanco ejecute ese tipo de labores (...)Ellos en cierta forma son muy defensores de sus derechos y de sus deseos, negociar con ellos es un poco complejo en la medida en que ellos no quieren estar sometidos y sentirse como usted mismo lo expresaba anteriormente, esclavos (José Alejandro Mesa, Entrevista en obra, 2014).

Néstor: es como ahí en el puente de la madre Laura, allá apareció una pila con gas, de explosivo se midió y tenía 49, entonces un encargado que ponen ahí que no sabe de pila, yo le decía: "compadre haga esto, ponga acá", pero un día que llegué tarde y el man fue y me hizo que me hiciera un memo, porque la entrada es a las 7 como dice el contrato: entrada a las 7 y salida a las 5 ipero el ingeniero me exige que tengo que llegar a las 6:45! y yo dije: "esto no lo firmo porque el contrato me dice que debo estar a las 7 en punto en la obra, no a las 6:45", y el ingeniero: "pues si no es así se me va", yo le dije: "me voy pero te hago la carta y te demando" (Néstor Arboleda, Entrevista en Pasolini, 2014).

Aunque el estereotipo se ha desechado en muchas ocasiones como recurso analítico, es también una forma de conocer a partir del análisis cultural y la forma de producción de imaginarios sociales. Los estereotipos nos sirvieron como presupuestos a cuestionar, como en el caso de la naturalización o biologización de la exclusión, y en otros casos para comprender situaciones que son leídas de acuerdo del rol de quién las enuncia, especialmente para el caso de la imagen de que los pileros que reclaman derechos laborales son problemáticos (Serna, 2011).

Los hombres con los que trabajamos conocen las normas de su trabajo, han intentado sindicalizarse, defienden sus derechos y prefieren no tener un horario fijo de trabajo, sino de acuerdo al sueldo y a la productividad que alcancen en el día; para nosotros esto es una forma de insubordinación, frente a horarios de trabajo extensos y desproporcionados en relación al desgaste físico que produce este oficio. Constantemente hay alusiones de los pileros a la rudeza del oficio, aunque también a que lo prefieren al del obrero raso porque logran un salario mayor, aunque estén expuestos a un riesgo más fuerte. En su mayoría querrían tener otro oficio.

Luis: jah! y lo de la obra blanca porque lo que por ejemplo ella estaba explicando (se refiere a la esposa de Néstor), uno para empezar a ganarse -uno como ayudante, porque uno no tiene conocimiento de estucar, de ser pegador, revocador, empalmador- pues no saca 600 ni 700 sino 200 y pico (mil de pesos) como ayudante y de ahí es que uno va adquiriendo el conocimiento para poder superarse, pero entonces uno no se aguanta hasta allá que porque esto y porque lo otro, y sigue uno siempre con lo mismo. 
Leo: ¿Lo que dices tú es que el proceso para llegar a ganar bien en obra blanca es muy lento, mientras llega allá hay que ganar como ayudante?

Luis (joven): hay que ir aprendiendo y escalando, haga de cuenta como ud. cuando inicia a estudiar. Néstor: mientras que los arriendos el más barato vale 300 mil pesos.

Don Luis (mayor): o ingresar al Sena y hacer un curso, pero mientras eso, qué si uno tiene que ver por la casa y por la familia, mientras uno se mete al Sena a hacer un curso se pone los horarios, eso no le da para ir a trabajar tampoco (Conversación, Grupo focal, 27 abril de 2014).

La biologización de los afros en este oficio es una muestra de un racismo estructural sedimentado en la población no afro, actitud que puede rastrearse en continuidad con la colonia y el pensamiento esclavista. De acuerdo con Peter Wade (1997) los discursos racializantes son también naturalizantes, y convierten elementos biológicos en significados raciales a partir de procesos ideológicos históricos y paulatinos. Apelar al argumento biológico es una forma de plantear la imposibilidad de cambio, sin embargo y como Wade (1997) y Restrepo (2010) lo han planteado, este argumento ya ha sido ampliamente debatido por algunas autoras feministas como Haraway y Butler, quienes demuestran las formas sociales en la que también se construye culturalmente lo biológico.

A principios del siglo XX todavía predominaba una idea de inferioridad racial del afro, se consideraban fuertes y resistentes para el trabajo, pero inferiores moral, intelectual y políticamente. Este repertorio clasificatorio fue la base para asignar valores morales, espirituales o reglas a las relaciones sociales a determinados tipos de color de piel o de talla construyendo jerarquías morales e intelectuales de las "razas"; la infantilización y deshumanización son esenciales a este proceso y se materializaron primero con argumentos religiosos y posteriormente raciales, en los que algunas personas quedaban más cerca de la naturaleza (lo salvaje) y otras de la cultura (lo civilizado) (Restrepo, 2007) (Restrepo \& Rojas, 2010) (Wade, 1997) (Arocha, 2005). En ese sentido el racismo es una forma de colonialismo a partir de discursos que inferiorizan a los colonizados, única manera de garantizar su servidumbre y que para algunos autores está íntimamente relacionado con la división del trabajo (y la división sexual) en el capitalismo (Restrepo \& Rojas, 2010).

"Estos planteamientos de la 'raza' como alma o de su relación con la 'cultura' introduce un registro que se distancia de una restricción de la noción de raza a un ámbito estrictamente 'biológico'. Parece estar en correspondencia con aquello que han indicado distintos académicos para América Latina. Marisol de la Cadena (2004) ha insistido sobre este punto mostrando con sus trabajos centrados en el Perú que la 'raza' es articulada apelando a la 'cultura'. En el mismo sentido, Peter Wade (2003, p. 271) sostiene que para América Latina no se pueden limitar las clasificaciones raciales a criterios estrictamente biológicos, pues a menudo son criterios de orden cultural los que constituyen estas clasificaciones" (Restrepo, 2007, p. 50).

En los años 90 valía un metro 30 mil pesos ahora lo compran a 10 mil pesos. El revoque está mejor pago que la pila, el enchape, la pintura, todo eso está mejor. Lo que pasa es que la pila es un trabajo muy cansado, muy matado, entonces uno trabaja de 7:30 de la mañana a 3:30 de la tarde, 4 de la tarde ya llega uno a descansar, pero así en los otros trabajos siempre arranca a las 7 de la mañana y va saliendo a las 6 de la tarde (...) Habíamos acordado ochocientos cincuenta quincenal y nos llegaron cuatrocientos sesenta y entonces cuando nosotros reclamamos empezaron a hacer una lista para echarnos a la cantidad que reclamamos jno podíamos reclamar lo acordado! y para mí son muy inserios esta gente, si no valoran el trabajo de los pileros. Cuando fui a reclamar la liquidación me dijeron que posiblemente dentro de quince días, pero no da, eso con seguridad es que era una vaina como evadiendo a uno, como quererlo sacar de la oficina. Ahora llevo los papeles pa' otra empresa. Hoy vine fue a reclamar la liquidación y no me quisieron mostrar cuánto viene de liquidación ni nada, si no disque: firme ahí una orden pa' consignar y listo... (Néstor Arboleda, Entrevista en obra, 2014). 
Los hombres con quienes trabajamos son todos del departamento de Chocó, llegaron a Medellín en busca de opciones laborales y terminaron en este oficio por su experiencia en minería o porque algún conocido trabajador de las pilas, los recomendó y les enseñó a ser pileros. La minería es un oficio extendido en la región y en otras regiones del litoral Pacífico (Friedemann, 1974), en el que los pileros aprenden muchas de las aptitudes que después les servirán en la pilería; en el siglo XVI los afrodescendientes fueron introducidos bajo el régimen esclavista como sustento de la floreciente economía minera del oro (Álvarez, 1979), y desde allí puede rastrearse la racialización de este oficio.

En un principio se utilizó la mano de obra indígena en las minas, pero la hostilidad de los indios y su aparente incapacidad para sostener un tren de trabajo sistemático en las minas de aluvión, dictaminaron la temprana utilización de la mano de obra negra. Muchos mineros, con experiencia en el interior de la Nueva Granada, creían indudablemente que los negros por razones tanto físicas como legales, se adaptaban mejor al trabajo en esa región tropical. Por consiguiente, en 1704, sólo diez y seis años después de que los españoles habían asegurado su dominio en el Chocó, se habían importado a la región más de 600 esclavos. Dos décadas más tarde, en 1724, había 2.000 esclavos y su número aumentó constantemente hasta 1782, año en que se registraron 7.088 esclavos. (Sharp, 1976).

Esta tradición minera se ha convertido en una justificación para su adscripción al oficio de excavación y construcción de las pilas y tal y como se usara en la esclavitud para la "importación" de población afro a otras ciudades por sus "aptitudes" para esta actividad.

Estamos camellándole a este queisho, esto en bogotá se llama queisho (caisson en francés). Aquí en Medellín le decimos pila. Llevo 32 años, soy antiguo en esto, toda la vida camellando en esto, llegue aquí el 3 de mayo del 80 y vea. Soy chocoano. Vea construyendo todo el poblado, envigado, sabaneta ¡no, que le dijo yo! somos exportación también" (Ceferino Mosquera, Entrevista en obra, 2014).

Para Peter Wade (1997), las imágenes que se han construido en Medellín sobre los negros están asociadas al trabajo servil, lo que hace que en la ciudad hayan cerramientos que los dejan en su mayoría como habitantes de barrios periféricos y con trabajos de bajos ingresos.

(...) Para responder por cómo la desigualdad racial afecta a los chocoanos, se tiene que recurrir a las explicaciones basadas en una experiencia particular de esclavitud que los dejó en una región periférica, la explotación de la mano de obra que utiliza estereotipos de los negros como una justificación, el cierre de un grupo étnico que niega a los "forasteros" -y en especial a los negros- el acceso a ciertas oportunidades, la colonización de un territorio de frontera que es legitimado en términos del atraso de los negros y los conflictos sobre el capital simbólico del color y el prestigio que usa conceptos sobre el carácter primitivo y la fealdad de lo negro. (Wade, 1997, p. 399)

Néstor y Aurelicio quienes se desempeñaron como mineros en su tierra natal, comparan el oficio de la minería con el de la pilería y comentan que:

Aurelicio: En la mina se tiene que estar sumergido en agua día y noche. A todo momento. Y en la pila no le toca a uno a veces tocar agua porque muchas veces sale el terreno seco.

Néstor: No, y donde le toca a uno bucear, uno baja 14, 15 metros y los oídos doliéndole.

Aurelicio: Imagínese eso, salpullido, lleno de agua, eso es difícil.

Víctor: Bueno y tampoco hay una seguridad social.

Aurelicio: Ah, tampoco hay porque es que en la mina no hay. Bueno yo creo que ahora de pronto estas minas de socavón sí creo que les exigen

Víctor: Pero ahí son trabajadores, ahí no son como tradicionalmente es ser dueño de lo que...

Aurelicio: Pero los pequeños mineros no tienen capital para eso, los pequeños mineros no, no les da. Y eso ya para una empresa, ya con una mina, si es legalmente una empresa, ya sí debe tener afiliados a sus trabajadores. Ya es una mina que ya tiene más. 
Víctor: ¿A usted le hubiera gustado trabajar en una mina de trabajador o como generalmente trabaja el pequeño minero que es de cuenta propia? ¿Cuál es mejor?

Aurelicio: Me gustaría de cuenta propia.

Néstor: La propia de uno mismo. Nosotros porque somos nativos del Chocó, siempre compramos su motobomba, para armarnos su empresita para sacar el oro.

Aurelicio: Para uno sobrevivir ¿por qué? porque cuando usted le trabaja al otro tiene que estar expuesto a las órdenes de otra persona, pero si usted trabaja para usted mismo usted mismo es el que va a dar sus propias órdenes. Claro y administra su propia plata, no hay que estar con otro esperando que de pronto que otro tiene que decirle a usted tome, o...

Néstor: $Y$ también eso es muy explotador el sueldo que se está ganando un minero. Porque un minero se está ganando setecientos mil pesos mensuales, bueno con todo: la comida y la dormida, pero una mina da mucho oro.

Aurelicio: Una merca, dependiendo el número de la familia también. Porque hay que mirar el núcleo familiar, porque si el núcleo familiar es un núcleo bastante grandecito, así mismo hay que invertir, y si es un núcleo de familia por pequeño que sea, tres o cuatro personas, también, pero sí, hoy en día para uno poder subsistir un mercado para una casa, tiene que ir mercando siquiera de trescientos pa'arriba" Don Luis: opción a la minería no hay porque ahora el gobierno está persiguiendo mucho la minería, en el chocó ya la minería no está dando nada, se están yendo para Nariño o para otro lado (Conversación Grupo Focal, 2014).

El racismo estructural alrededor del cual se cierne el estereotipo que consideramos más grave (que los afros son aptos para el trabajo bajo tierra), es en el que nos centraremos. Esta forma de racismo es evidente cuando se hace observación participante en las obras, en el sentido de que ningún afro es ingeniero y en el área de pilería predominan, cuando no son todos, afro.

Los hombres que nos contaron su experiencia están excluidos de labores intelectuales y en cambio, incluidos en labores físicas, especialmente oficios pesados. Todos manifestaron deseos de tener otro trabajo (ser músico y cantante de vallenato, tener un restaurante, tener una chaza de frutas, ser chef o cocinero, tener un taxi, trabajar de cuenta propia), ninguno de ellos lo ha llevado a cabo, y dentro de las razones expuestas está la falta de recursos, la no culminación de estudios y la falta de oportunidades (Notas de campo, 2014). Hay una sensación de adscripción al oficio, de imposibilidad de dejarlo, pues aprender otro requeriría tiempo escaso frente a necesidades diarias apremiantes.

Si bien una de las categorías centrales de la investigación era el racismo, en las primeras entrevistas esta categoría no fue expresada por los participantes. Tal y como propone la metodóloga Rosana Guber (2005) las categorías analíticas deben surgir de los entrevistados y no ser forzadas en las preguntas de una entrevista. En la descripción anecdótica de su vida laboral, familiar, social, la categoría de racismo tuvo diversas formas de expresión: humillación, ignorancia, irrespeto, exclusión, falta de oportunidades, etc., pero las alusiones a actitudes de exclusión o de subordinación extrema por el color de piel fueron abundantes, así como las frases "negro hijo de puta" o "negro tenía que ser" (Notas de campo, 2014).

Don Luis (mayor): Si eso se mira mucho, todavía sigue, disimuladamente pero sigue, a los pileros los tratan mal, el que quiera eso y el que no que se vaya, uno no puede reclamar el derecho al trabajador, porque lo tachan de sindicalista y lo botan.

Néstor: disimuladamente no, porque en el caso de nosotros los pileros nos tratan mal. Nosotros llegamos a una obra y nos dicen: el precio es este el que quiere así y el que no que se vaya, la expresión es así. Y otra cosa que ya uno no puede reclamar sus derechos como trabajador, ya lo tildan como sindicalista, una cosa y la otra, lo van aplacando a uno porque como uno tiene sus necesidades también, entonces uno dice: no digamos nada porque estamos trabajando. 
Don Luis (mayor): "A uno nos han negriado... por ser negros... jahh sí! Vamos a pelear eso, por vías legales: "uy que disculpe. Que no sé qué." En Bancafé, ahí hicimos nosotros las pilas, había un machinero (el que rompe la calle), grande, y un ingeniero, entonces el man llegó como bravo: "negro tenía que ser este hijuetantas" y el negro apagó la máquina y se fue calladito hasta la oficina y lo cogió y le pegó... le dieron bien duro por el racismo; lo mandaron para otra parte, lo cambiaron por otro trabajador".

Néstor: la mayoría de empresas ahora casi no están dando contrato sino es al día, y a nosotros nos llevaron a Santander, San Andrés Santander, por allá por Málaga y nos llevaron con mentiras, disque 850 (mil pesos) nos iban a pagar quincenal, y cuando llegamos allá eso era mensual, nosotros dijimos: "nos regresamos" y ahí mismo el ingeniero: "no, quédense muchachos que vamos a arreglar el precio" ya me tocó de líder y hablé con el ingeniero, hablé con ese tipo y arreglamos los 850 quincenal más ahí encima le dije: "hermano, tiene que darnos el subsidio de transporte que es obligación que son como 72 mil pesos", no tuvo más, pero allá casi era el trabajo obligado, los domingos obligados, la hora obligada, los sábados uno trabajaba, se le cumplía el horario a las 10 y tenía que trabajar hasta las 5, bueno ese trabajo era así... (Conversación, Grupo focal, 27 abril de 2014).

No obstante, las relaciones laborales analizadas muestran la insubordinación del afro y su conocimiento de derechos laborales, en parte tras haber sufrido vejaciones en ese sentido. Paralelamente, ello viene con la constante amenaza de perder el trabajo por reclamar lo que es justo. A su vez, no siempre se respeta el contrato, o se da de manera verbal incumpliendo las condiciones pactadas; esto tiene implícita una relación laboral marcada por la sensación de posesión del trabajador que se refuerza cuando el trabajo no es en la ciudad de residencia del pilero, lo que lo obliga a permanecer en un espacio dotado por el jefe. Historias sobre verse obligados a trabajar los domingos, no respetar los tiempos de descansos, superar la jornada laboral establecida legalmente, entre otras, surgieron en un ejercicio de cartografía social en el que exploramos los tránsitos de los pileros y de sus compañeras, quienes se dedican fundamentalmente a labores domésticas o de cuidado remunerado.

Imagen 2. Registro Cartografía (2014)

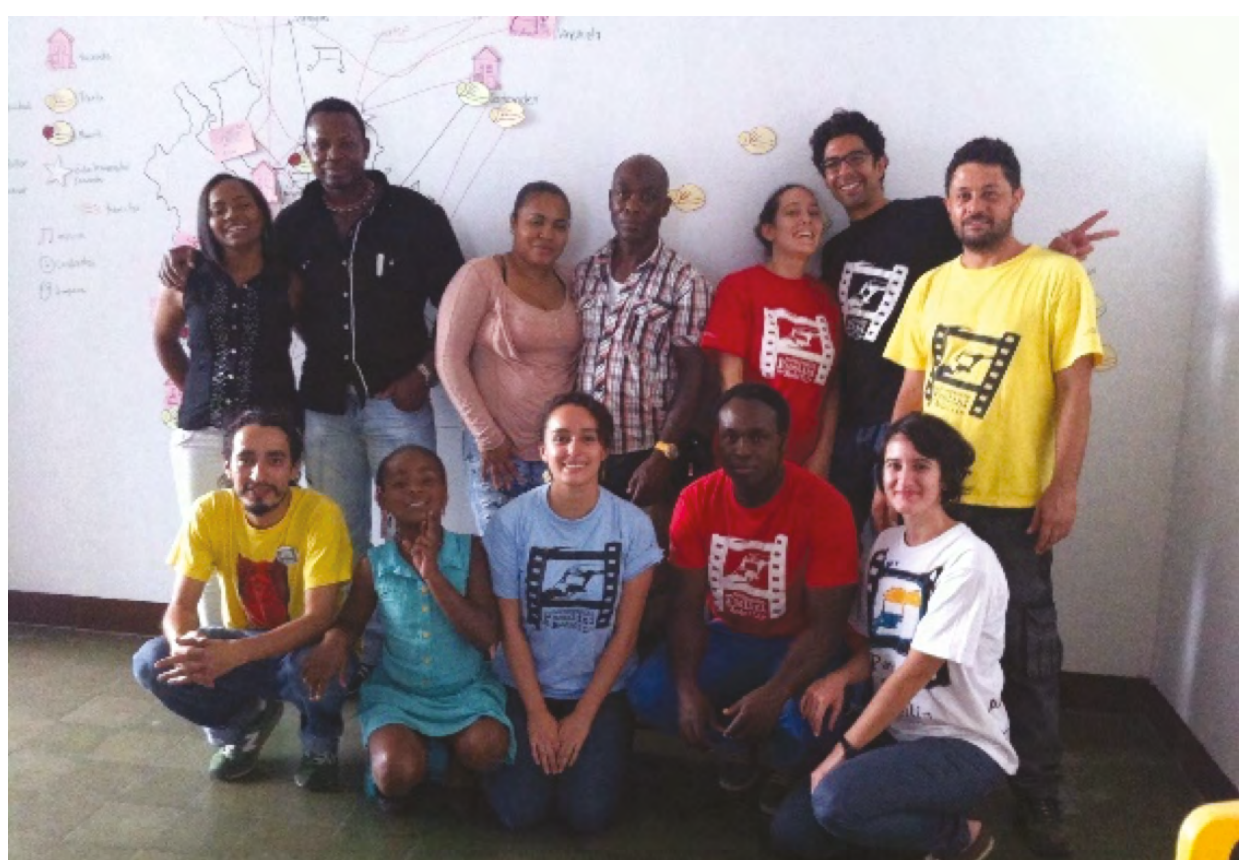

Fuente propia 
Si bien el oficio se ha ido regularizando y cada vez hay más control sobre la contratación y la seguridad laboral, durante muchos años no fue así y los pileros que llevan más años en este trabajo no tienen el tiempo cotizado para la jubilación. Además, el panorama prestacional es incierto y la edad necesaria para jubilarse aumenta, lo que genera incertidumbre en los pileros porque el desgaste del cuerpo en este trabajo llega antes que la posibilidad de retirarse a descansar.

Luis (joven): En cuanto al futuro de uno como pilero tiene que ser un milagro de dios se puede decir, porque uno como pilero si ud. llegó a los 70 años por decir algo, y está cotizando en el seguro que se pueda pensionar, pues va a gozar la pensionsita. Pero el que uno vaya a hacer otra cosa diferente, pues tiene que ser decisión de cada uno porque digamos uno no es que vaya a ahorrar plata para yo ir a montar un negocio, o voy a salirme de la pila en cuanto a que unos no tenemos más conocimiento sino de hacer eso. Si yo me voy a hacer eso no me da, si me salgo de aquí no me resulta una cosa... entonces uno sigue aferrado a eso y no más, entonces pues yo digo que tiene que ser un milagro como de dios que uno se gane un chance, una lotería, para uno salirse o retirarse de eso de una vez (Conversación, Grupo focal, 27 abril de 2014).

Es decir, se genera una red de desigualdades en la que algunos sujetos quedan atrapados y que son las que han llevado a distintos autores a hablar de racismos entretejidos en diferentes relaciones sociales (Wade, 1997). La migración de familiares desde el Chocó, en busca de nuevas oportunidades que terminan en este nicho asegurado por la ingeniería antioqueña que concibe esta labor como idónea para los afrodescendientes, favorece una exclusión sistemática.

Javier: cuando ud. pregunta que por qué la mayoría llegamos y sólo nos metemos a la pila, es así. Que viene mi hermano del Chocó llega el man y no le dicen "bueno por qué no te pones a estudiar esto o trabajar lo otro" sino que de una "yo estoy trabajando en una obra por allá y allá hay un trabajo así y asá, vamos de una" de una lo meten a eso, no le dan la oportunidad de que él aprenda otra cosa, porque yo tengo mi hermano y mi hermano viene y por mi parte, que aprenda otra cosa. Patricia: pero eso ya depende mucho también de uno mismo porque por ejemplo yo le insistí tanto a mi hermano, tantas opciones, otras posibilidades y él como que no

Jaime: El hijo que se meta a la pila es porque él quiere no porque yo lo lleve, yo no quiero lo mismo para él. Él trabaja en una peluquería.

Luis (joven): El Trabajo en la pila es muy peligroso y duro, y hay muchas humillaciones, en la construcción uno prácticamente no aprende nada, es lo mismo, es muy repetitivo. Es el más duro de la construcción, si fuéramos unidos sería mejor el pago.

María: desde acá viajan pileros, pero hay muchos de Chocó ¿En Chocó también hacen pilas y viajan para otras partes, o la gente se viene a formar como pilero acá en Medellín así sean de chocó?

Néstor: No, en Chocó apenas ahora es que se está viendo la pila allá, sino es que como uno trabaja la minería, tiene la verraquera, la fuerza y la malicia para trabajar la tierra ¿sí? Y uno a pesar que no estudió la geología, uno más o menos sabe: después de esta capa de tierra aparece esta otra, así, esta tierra puede caer, esta no, y así, esa es la malicia.

Javier: y quizá hay pileros que no saben nada de eso, aquí vienen personas que no saben nada, pero lo que le dije ahora, si llegó mi primo, mi hermano, de una lo meto.

Don Luis: por ejemplo, en el caso mío que yo tengo unos hermanos en el Chocó y no tienen estudio ni nada, si van a llegar a la ciudad ¿qué se ponen a hacer?, ¿yo cómo le voy a decir: vayan y busquen trabajo en ese edificio, vaya a la gobernación? si no saben nada, entonces yo tengo que conducirlo donde le pueda enseñar, lógicamente ¿qué le digo yo? véngase y si tengo el compañero le digo: búsquese otro socio que le voy a enseñar a mi hermano. (Conversación, Grupo focal, 27 abril de 2014). 
Sin embargo, y de acuerdo a lo observado encontramos que la clave emancipatoria para los pileros es la educación de sus hijos y en ese sentido se da en la generación siguiente de un pilero instalado y con tradición, trayectoria y conocimiento en el oficio. Si él ya está situado, conoce el oficio, tiene redes laborales y le va bien, es más probable que haya hecho énfasis en la educación de sus hijos y que haya podido ofrecérsela. Los pileros con quienes realizamos entrevistas, grupos focales y observación participante dijeron trabajar arduamente para que sus hijos pudieran estudiar y no tener que trabajar en las pilas, algunos habían logrado entrar en la Universidad, ninguno se desempeñaba como pilero y sólo un hijo de un pilero quería trabajar en lo mismo de su padre, por el deseo de tener dinero rápidamente (Notas de campo, 2014). La educación sigue siendo percibida como una forma de movilidad social ascendente y de romper barreras impuestas por el racismo cultural, que da la sensación de imposibilidad de acceso a trabajos intelectuales y que en muchos casos efectivamente las crea.

Habría que hacer una investigación sobre los hijos e hijas de los pileros para identificar qué pasa una vez terminan sus estudios profesionales y qué tanto logran ser absorbidos por el mercado laboral.

Entre afirmarse en el lugar que otorga la estructura y liberarse o desmarcarse de ella (Tapias, 2010) también encontramos la opción de trabajar paralelamente en lo que sería su sueño: Néstor, Luis y otros pileros que no hicieron parte de la investigación habían conformado un grupo vallenato con el fin de encontrar en la música la posibilidad de entrar y salir de espacios colonizados que se deshacen aunque sea momentáneamente por la acción creativa. Sostener este otro trabajo que por lo general se realiza en las noches y los fines de semana es difícil y poco estable, lo que los obliga a seguir en el oficio de la pila y genera una contradicción importante en su vida. Para el documental producto de esta investigación, Néstor compuso una canción que representa su interpretación del trabajo y con el que queremos cerrar este aparte del texto:

Yo Trabajo de sol a sol, porque yo no tengo plata, me tocó meterme a esos huecos con la barra y con la pala, me tocó meterme a esos huecos con la barra y con la pala. Porque el que tiene la plata manda, el que tiene la plata manda. Como yo no tengo plata no soy rey de las muchachas, como yo no tengo plata no soy rey de las muchachas (Néstor Arboleda, Canción yo trabajo de sol a sol, 2014).

Sorprende el parecido del título de la canción con la clásica obra de Arocha y Friedemann (1988), pues Néstor sin conocerla coincide plenamente y evoca esa forma de trabajo incesante que raya con la explotación (de sol a sol).

\section{Reflexiones metodológicas}

Esta investigación pretendía identificar las representaciones de los pileros sobre su oficio y hacer públicas las condiciones de trabajo de una población que hace una labor indispensable pero invisible (Hugo Mosquera, Reuniones trabajo 2014) y se hizo a partir de un documental etnográfico. Debido al poco uso de la antropología visual en la vida académica de Medellín queremos también hacer unas reflexiones sobre el uso de esta metodología y de las técnicas asociadas a ella en este caso.

La apuesta metodológica se resume en tres acciones concretas. Dialogar, Ficcionar, Reflexionar. El primer propósito metodológico es la co-creación de narrativas, la incitación a una antropología visual desplegada sobre lo cotidiano con los participantes. Para empezar, le presentamos la propuesta a quienes serían nuestros principales informantes (Néstor y Aurelicio) y ellos a su vez fueron relatando historias y esbozando cómo se imaginaban el documental. Hicimos entrevistas semiestructuradas, conversaciones informales, grupos focales con proyección de referentes de la antropología visual y observación participante en obras de construcción, para finalmente con ello, construir una primera escaleta que fue presentada a los participantes y sometida a modificaciones. El equipo investigador tuvo 
también discusiones sobre esta primera versión y en grupos de a dos se construyeron tres versiones de guion, que fueron asimilados en uno sólo, perdiendo y ganando partes de cada uno. Esto conllevó discusiones sobre el alcance de la horizontalidad en la interacción entre investigadores e investigados, para lo que se recurrió a encuentros dialécticos (Arango \& Peréz, 2008), motivados por tensiones que dejan ver sentidos y marcos de representación de las experiencias cotidianas. Es decir, se entiende que la antropología visual implica también el posicionamiento de significados múltiples, crea representaciones que requieren ser discutidas; esta discusión por supuesto, no excluye a los sujetos investigados. La antropología visual propicia nuevos mecanismos de identificación a partir de una escritura en un sentido ampliado, posible tras el uso de tecnologías como cámaras versátiles, redes de información digital que se transfiere y es manipulada, archivos fotográficos, imágenes mentales o versos en construcción.

\section{Algunos aspectos necesarios para estos encuentros dialécticos son:}

El diálogo: como planteamiento metodológico, nos sitúa en la práctica de una antropología dialógica (Rouch, 1995) y posoccidental (Arroyo, 2007). La filosofía occidental ha perseguido el ideal de pensar objetivamente; es decir, un proceso por el que un sujeto piensa sobre un objeto con la pretensión de que ese pensamiento objetivo sea una doctrina de la realidad. El diálogo en cambio propone el intercambio, parte del presupuesto de que la realidad es intersubjetiva, es decir, que se trata de un objeto al que el sujeto se acerca a través del diálogo con otros sujetos y que se transforma en ese proceso. Explorar paisajes culturales y políticos en procura de otros sujetos, otras miradas y a través de la exploración artística fue el diálogo al interior del equipo de investigación que desarrolló el trabajo en torno a la producción del documental "ni libre ni asalariado" integrado por ocho personas en formación o formadas en antropología, sociología, comunicación y lenguajes audiovisuales, cuatro de ellas mujeres, los otros cuatro hombres, y entre todos, un hombre y una mujer afro que nos reuníamos periódicamente y en jornadas de debate y reflexión construyendo derroteros.

¿Qué entendíamos al interior del equipo por antropología visual?, ¿Qué conexión podría establecerse entre la comunicación audiovisual y la antropología?, ¿De qué forma la sociología puede aportar al cuestionamiento antropológico que nos proponemos? Para acercarnos a posibles respuestas indagamos como referentes fragmentos de películas que vimos con los participantes (Petit a Petit (Rouch, 1971); F for fake (Welles, 1974), junto a videos de vallenatos que el protagonista/personaje principal de la etnografía nos compartió por ser su género musical); además leímos artículos científicos y reflexiones que la Corporación Pasolini en Medellín ha venido elaborando a través de su línea de producción "Narrativas de la diáspora afro descendiente", con más de 10 películas en estudios afro colombianos (Tapias, 2014).

Un segundo momento del diálogo fue intergrupal. Los grupos focales fueron escenario principal de este encuentro entre pileros y "pasolinis", en los que se prepararon posteriores encuentros, como el rodaje y momentos de la posproducción. Se editó un teaser con algunas entrevistas previas para su visualización, para que los pileros identificaran similitudes y diferencias con sus compañeros, y fueran imaginando cómo sería la propuesta documental que les llevábamos. Todo ello bajo premisas etnográficas como inmersión, observación y registro. De este modo, el diálogo al exterior del equipo y con los actores sociales en torno a los cuales desarrollamos el proyecto de investigación, se dio en sus terrenos sociales y comunicativos: sus hogares, sus barrios, los lugares de trabajo, los lugares de encuentro para el trabajo o para el ocio como parques o el bar del barrio o en lugares como la Corporación Pasolini y Cepafro. En torno a los pileros identificamos los Parques de Berrío y San Antonio (lugares de encuentro y de contratación) y algunas construcciones. En la 
búsqueda de un pilero que hiciera música, y que de alguna forma explorara a través de la creación artística espacios de libertad o resistencia estética, recorrimos algunas construcciones hasta que encontramos a nuestro protagonista y un grupo de vallenateros con quienes sostuvimos un diálogo hasta el final de la producción. Esto para recordar que la antropología visual que practicamos es una antropología dialogante.

La exploración estética: Este proceso de investigación no estaba dirigido a que nuestros interlocutores aprendieran a hacer películas, sin embargo, uno de los protagonistas recibió algunas indicaciones y exploró su lugar de trabajo con una Go Pro (la mayoría de sus planos están incluidos en la película) y recibió unas sesiones para aprender a editar, de las que desistió rápidamente por sus ocupaciones laborales. La idea era construir la historia de su vida y recrearla, usando elementos documentales y puestas en escena cuando se requería representar algo que había sucedido. El lugar de trabajo era central para la investigación, pero no siempre pudimos ingresar a las obras, por lo que la labor del protagonista como camarógrafo, logró cubrir otros aspectos esenciales de la pilería como la excavación a profundidad. Además, se procuró acercarse a los contextos más íntimos de los personajes, abriendo posibilidades para ver a través de imágenes la historia de su familia y la intimidad de su hogar y forma de vida.

El culmen del enfoque estético lo da que en el documental se subvierta la lógica realista y se asuma la representación como realidad: es decir, que se integren elementos de ficción (como incluir en el documental un videoclip que elaboramos con Néstor para su canción Linda Chocoana) y que se recurra frecuentemente a la puesta en escena con elementos realistas y recreados o ficcionados totalmente, en caso de ser necesario. Esto nos pone de inmediato en la reflexión ética y política sobre quién y cómo se construyen las representaciones culturales de lo que se observa. Se trata de un problema que enfrentamos con etnografía experimental, una avanzada metodológica que mina la idea de realismo en la escritura etnográfica y sus patrones retóricos, al centrar parte de su interés en la manera como la experiencia de campo y los datos sensibles que arroja, son convertidos en textos sobre una totalidad cultural (Marcus \& Cushman, 1982).

En ese sentido, retomamos el argumento del cinema vérité que contrario al cinema directo u observacional, "se definirá por la aceptación de la presencia de la cámara como catalizadora de la acción y la inclusión de la subjetividad del director en el film. La cámara debe ser una cámara viviente o una cámara participante. El cinema vérité es una cierta forma de provocación (...) Esta visión del cine lleva a Jean Rouch a anclarse firmemente en la ficción, a contar historias, al relato etnográfico, a la etnografía-ficción" (Ardévol, 1998; p. 230). En este caso, se reivindica el encuentro y reconocimiento mutuo: entre realizador y sujeto filmado y no se anula la postura del realizador en el encuentro. Todo ello partiendo de la mediación de la cámara, pero entendiendo con Jean Rouch que la mirada de la cámara es una mirada teórica, y por eso un documental (o película) puede ser una narración etnográfica (Ardévol, 1998; p. 233).

La ficción: como hecho metodológico sintetiza la apuesta de la re significación y la re elaboración. Se trata de un debate entre el conflicto social, la vida de los personajes y el conflicto dramático, o la representación dramática de la vida de sus personajes (Arango, 2012). Los ejercicios para esto incluyen prácticas narrativas orales y escritas que nos permiten acercarnos al mundo de nuestros interlocutores y con los que se construye otra historia que los agrupe. En los grupos focales tuvimos la oportunidad de escuchar la música del protagonista de la película, acompañada de algunos de los integrantes de su agrupación (muchos familiares) y discutimos sobre la discriminación, las condiciones salariales, su deseo de organización y unificación salarial, las variaciones temporales del oficio, sus familias y formas de vida a partir de los viajes de trabajo; también preguntamos a los pileros qué aspectos deberían estar en un documental sobre su oficio y en ese sentido fuimos 
mediando intenciones. Los relatos del cantante (Néstor) y las elaboraciones musicales, tienen un papel central en el documental, porque es la inflexión creativa, la que consideramos el mejor escenario para burlar el racismo estructural y el lugar en el que se encuentran los pileros. De esta manera tratamos de acercarnos al sentido de la vida de nuestros personajes, a su particularidad, a los rasgos de una identidad móvil, e insertar esa otra posibilidad de la reflexión sobre el lugar del arte en la etnografía que pone en cuestión los diversos elementos retóricos de los que el autor etnográfico se sirve para la construcción de sus textos (Behar, 2007; Wacquant, 2007), mezclando de manera consciente el presente performático de la etnografía, con devaneos literarios y análisis de contexto (Behar \& Gordon 1995).

Hemos hablado acá de puesta en escena, pero de acuerdo a la propuesta metodológica que esbozamos, preferimos referirnos a la puesta en forma, para considerar incluso cómo la cámara participa de algo que debíamos distinguir de la simple puesta en escena (o el trabajo de los actores). La adaptación que implica la ficción nos permite pensar que la historia puede volverse a contar y que estas perspectivas son igual de válidas. Tal vez este sea un principio de justicia, una de las maneras más radicales que ha instaurado esta reflexión es la concepción de la etnografía como ficción, que a partir de las tendencias dialógicas de Rouch y Geertz, busca yuxtaponer narraciones geográfica y discursivamente localizadas de autoridades dispersas (Clifford, 1999), y/o diversas formas de inscripción de lo cultural a manera de variaciones (Taussig, 1987).

En la ficción se da la posibilidad de que los participantes puedan REhacer (lo que los actores hacen y los modos en que lo hacen), REsignificar (lo que los actores significan y los modos en que lo representan) y REsentir (lo que los actores sienten o experimentan en su relación con el territorio).

Cocinar y mapear: fue lo que hicimos para lograr el delineamiento de una territorialidad etnográfica -parafraseando a Acosta \& Garcés (2013)- para ver cómo hay una apropiación del territorio (audio visual y etnográfico) a partir de la mediación comunicativa y etnográfica.

Es claro que la etnografía no implica sólo la inclusión del sentido de la vista y la escucha, el gusto, el tacto y el olfato son tan importantes como los otros para la comprensión cultural y la asimilación de percepciones-otras. Por ello, hacer juntos el alimento, más si son sus recetas tradicionales, compartir historias sobre los ingredientes, comer juntos, alternarnos en las actividades que componen esta acción, para luego enfrentarnos a los mapas, constituyó un ejercicio significativo porque pudimos conectarnos con otras dimensiones espaciales y temporales que desencadenaron imágenes y anécdotas para el ejercicio etnográfico. Nuevamente, es implícito el tema de lo dialógico y la exploración creativa a través de formas narrativas.

César: Don Aurelicio nos estaba corrigiendo que en realidad lo que vamos a preparar no se llama un arroz clavado sino que se parece a un arroz bochinche por la cantidad de carnes que lleva por ejemplo, pero como este no lleva tal cantidad sino apenas unas cositas entonces doña Miriam lo llamó más bien arroz relajado (risas).

María: ¿Y el clavado como era?

Aurelicio: el clavado apenas es el arroz con el queso.

María: ¿Y el atollado?

Miriam (pareja de Aurelicio): también es con queso. Sino que es más mojado.

César: Y el otro es el arrecho. 0 el bochinche, cierto, cómo es, que le falta a ese.

Aurelicio: No, lleva de todo eso. Mortadela, el queso, manguera.

María: Pero doña Miriam si es de Venezuela ¿Por qué saber todas esas recetas?

Miriam: Porque mi papá es chocoano.

Aurelicio: Ella es levantada en las dos costumbres.

Miriam: pero igualmente en Venezuela en mi casa mi mamá hacía lo mismo. 
César: Su mamá también era chocoana.

Miriam: no, mi mamá era venezolana.

Aurelicio: Vivir con un Chocoano enseña las costumbres.

Leonardo: Y Aurelicio ¿aprendió las costumbres venezolanas?

Aurelicio: No. Porque yo con ella, o sea, nosotros siempre comemos la comida chocoana. La de las costumbres de nosotros. Cada que tengo la oportunidad yo cocino en cualquier momento en la casa. A veces está ella haciendo alguna cosa y yo estoy colaborándole ahí.

Víctor: En tiempos de la colonia la longaniza eran las carnes que no les gustaban a los españoles. Cierto, al amo de la casa no les gustaba y se las daban a los esclavizados para que comieran pues eso, cierto, lo que quedaba. Pero varios de los grupos que vinieron de África para ellos era un manjar, porque para ellos eso era incluso lo más delicioso allá en África. Entonces lo que creían que dejaban como desperdicio, era lo que mejor sabían hacer ellos y preparar. Y acá pues, lo que pasó es que la gente comenzó a organizar eso que dejaban como desperdicio como carne de mala calidad, se los dieron, y ellos comenzaron hacer de so un manjar y crearon con eso la longaniza. Y ya la gente pues acá en Colombia ya con el aporte español y la combinación de todas partes armaron la longaniza y es uno de los productos más ricos allá. Lo que empezó como algo denigrante terminó siendo como algo más bueno y más deleitable.

Aurelicio: Se sofríe, hace uno la verdura así.

Miriam: A él le queda mejor que a mí, mi amor, pásame la longaniza.

Aurelicio: Luego le echa la papa, los enredos, la pasta.

César: ¿Los cabellos de ángel?

Aurelicio: eso.

Miriam: él le dice enredo.

Aurelicio: en el Chocó le decimos enredo a esa pasta y lo pone a cocinar uno el enredo con la papa y luego cuando ya está que ya cocina la papa ya uno está próximo a bajar todo, le echa el queso le echa ahora sí el cilantro y lo deja que cocine unos diez minutos, cinco minutos.

Miriam: A no sí, el cilantro no puede faltar en la comida, y menos en una sopa.

María: ¿Patricia y dónde aprendiste a hacer el arroz que vamos hacer?

Patricia (pareja de Néstor): Pues yo soy chocoana y siempre hacíamos, allá le decimos bichera. Pues como que nos reunimos todos y cada quien pone y hacemos comitiva, pues, ahí entre todos en la casa. Arroz bochinche.

Miriam: Y al arroz bochinche también se le echa carne ahumada. Les faltó más de la mitad (risas). En el Chocó la familia mantenemos carne ahumada, por ejemplo la longaniza, esas cosas que son básicas en la casa, pues, la mayoría de los chocoanos... yo no soy de allá, pero yo viví allá." (Conversación con Néstor, Aurelicio y sus familias, cocina de guiones, 2014).

Así mismo, la metáfora de la preparación y cocción de los alimentos y de la reunión de los comensales, es la misma de la construcción colectiva de la película. Es otra forma de acercarnos, conocernos y crear en comunión. Esto es lo que en la Corporación Pasolini en Medellín se ha conocido como Cocina de Guiones, un espacio para la construcción colectiva de las producciones audiovisuales alrededor de la alimentación conjunta de ideas, alimentos y saberes

Grabar y transcribir: Una de las indicaciones metodológicas en diversos espacios es que la cámara llega de último, que los investigadores van primero, hacen contactos, se ganan la confianza de los interlocutores y luego los abordan con la tecnología de una forma casi concertada. En nuestro caso esto fue motivo de discusión puesto que podíamos optar por ello o por evidenciar el mecanismo de mediación y permitir que adquiriera naturalidad paulatinamente. Hubo espacios para una opción y otra: en la exploración que hicimos en 
busca de lugares donde se construyen edificios, en donde se hacían excavaciones profundas y donde seguro encontraríamos pileros, llevamos la cámara y fuimos interrumpiendo. Seguimos también la idea de que "La cámara etnográfica no es una cámara de vigilancia ni una cámara de televisión. La cámara no es una mera herramienta auxiliar, sino que la introducción del vídeo en la investigación antropológica modifica la experiencia etnográfica, la relación del investigador con el campo, la interacción con los participantes y la construcción y análisis de los datos" (Ardévol, 1998; p. 225), y en ese sentido preferimos ser honestos con su uso directo.

El uso de la cámara para el etnógrafo es funcional a la idea de la descripción densa, se obtiene de inmediato una descripción audiovisual y se ve hacer lo que está sucediendo en movimiento. Además, puede usarse como un detonante de la acción y como una propuesta y provocación para la actuación o la puesta en forma, para la creación de nuevas representaciones.

Además de la grabación, se realizaron entrevistas, conversaciones o grupos focales que ponían al interlocutor en un escenario privilegiado en donde contando su vida actuaban y se representaban ante la cámara. Luego nos dimos a la tarea de la transcripción y a ordenar lo transcrito en matrices de análisis con códigos o palabras claves, de tal manera que pudieran ser utilizadas para el video final, pero también para una segunda reflexión, pues la primera fue aquella dada en caliente, cuando el interlocutor hablaba. Las reflexiones de segundo orden (Luhmann, 1991) son vitales en el ejercicio investigativo porque es el momento donde los datos cobran relevancia, de otra forma tenemos información sin procesar que aún no dice nada al investigador. Una vez transcrito el material, fue puesto en común con los conceptos previos y los que surgieron del ejercicio etnográfico, a manera de códigos en vivo.

Como devolución, las imágenes que se llevaron a la sala de edición reconfiguraron los territorios para nuevas imágenes y en los espacios donde se ruedan las películas luego fueron exhibidas y en la exhibición participaron algunos pileros, aunque todos fueron invitados (Una obra de construcción, Corporación Pasolini en Medellín, el Centro de Desarrollo Cultural de Moravia, Cepafro, y las aulas de clase de algunos de los investigadores). Verse allí como protagonistas de una historia que no había sido contado, llenó de orgullo a los participantes y fue para nosotros el inicio de un proceso necesario de reconocimiento. Especialmente significativa fue la presentación en la obra, donde obreros, ingenieros y otro tipo de funcionarios se unieron para ver otra forma de representación de los pileros, de cierta manera, obró como una dignificación de su oficio y trastocó por un momento las relaciones de poder en el espacio. La voz estuvo en ese caso, del lado de los pileros.

\section{Construcción del guion: Notas, escaletas y guiones}

Con una formación en etnografía la mayoría de nosotros tomó apuntes y notas de los diálogos con los otros y de aquellos que se dieron entre nosotros mismos. Se conformó un dropbox (carpeta de archivos en la nube) compartido en el que había fragmentos de diarios de campo, fichas de textos y de fotos, transcripciones de entrevistas, y material que los miembros del equipo iban revisando según su disponibilidad y que después en los encuentros discutíamos. Hicimos actas de las primeras reuniones que eran retomadas en encuentros posteriores y a partir de allí fuimos estableciendo unos cronogramas. El guion lo veníamos escribiendo a partir de esas notas, que incluso circulaban como correos electrónicos.

Como se mencionó en trabajos de mesa logramos formular varias escaletas que fueron compartidas con los pileros, especialmente con los protagonistas (Néstor y Aurelicio), quienes hicieron sus aportes. Lo más concreto que logramos en esta fase de construcción fue un listado de más de 15 secuencias temáticas a través de las cuales abordamos el desarrollo narrativo de la historia. Para ello se codificaba la información según lo que se iba encontrando: la importancia de la pareja en la pila, los viajes y las implicaciones 
contractuales y familiares para el pilero, los peligros del oficio, la vejez y el trabajo, el racismo estructural o el leído como humillaciones, entre otros. Las sesiones de montaje en el papel fueron acompañadas de montajes previos pensando primero en las entregas parciales que debíamos hacer al Instituto Colombiano de Antropología e Historia pero también en vislumbrar caminos narrativos. Llegamos incluso a operar por turnos el programa de edición y comenzamos a agrupar algunas imágenes en función de esas primeras secuencias organizadas sobre el papel. Esto es bastante diferente a la forma personal e introyectada en la que trabajan los profesionales de la realización audiovisual, y lo es así porque para nosotros como investigadores sociales, ante todo, era fundamental el trabajo colaborativo. Por supuesto, esto genera dificultades, en el sentido de cómo hacerlo, cuál historia predomina, qué idea se posiciona y cómo articular esa mezcla de roles. Pero preferimos deliberar arduamente y en jornadas largas, que delegar el trabajo a un director y un editor.

Estábamos detrás de la construcción de un discurso, no sólo de una película, y uno de los principales problemas que afrontamos era el de quién narraba, desde dónde lo hacía y qué lugar ocupaba con respecto a los sujetos narrados. Una de las primeras discusiones del proyecto versaba sobre si las preguntas de investigación surgen de los investigados o de los investigadores, algunos cuestionaban la mirada externa con temor de hablar por el sujeto investigado y otros consideraban la importancia del encuentro de culturas como experiencia etnográfica, pues ese encuentro propicia preguntas que en muchos casos no se le ocurrirían a quien está totalmente inmerso en su contexto. Un punto intermedio entre la identificación absoluta y el distanciamiento extractivista fue el de privilegiar la intersección, pues es en la diferencia donde aparece lo interesante (Corbetta, 2007). Pero teníamos un punto a favor del equipo de investigadores, entre nosotros, dos compañeros son afro descendientes y fueron la bisagra que nos permitió por ratos hablar desde la primera persona del plural donde estaban ambos puntos de vista culturales y étnicos.

Montaje y discurso: Notas, escaletas y guiones para montaje Después que se apaga la cámara, el montaje propicia un momento de análisis y sin duda la última oportunidad para componer una película (Pérez, 2012). Se trata de una fase que conjuga las prácticas de investigación etnográfica, o también de preproducción como son las mesas de trabajo y las cocinas de guiones con nuevos escenarios de discusión: el papel. El montaje continúa produciendo notas. Seguimos en campo. Lo REmiramos. Ya que las notas se apoyan sobre el análisis de las imágenes. El discurso de la película se materializa sobre primeros cortes, que a su vez se logran en medio de diálogos y negociaciones tensionantes en torno al significado que se va construyendo. Esta técnica de creación fortalece el diálogo y constituye la fase superior del conocimiento adquirido que termina evaluándose en función de la definición del material que se incluirá en el producto final. Es un momento de evaluación que permite repasar el material y las condiciones en las que se consiguió, una suerte de espacio para la reflexibilidad que exige cuestionar la mirada del investigador y su contrastación con la teoría ¿Qué es lo que censura o privilegia la mirada antropológica?, ¿Qué es lo que miramos cuando re-miramos?, ¿Por qué razones hemos seleccionado esos encuadres?, ¿Qué tensiones se establecen con lo que hay dentro del encuadre y lo que denominamos fuera de campo? La reflexión crítica no surge en esta etapa pero se consolida a través del proceso de montaje, última escala en el proceso de la realización audiovisual: el momento de la composición audiovisual, a partir de la selección del punto de vista, mientras vamos construyendo un discurso en el que quedamos bien situados investigados e investigadores, a partir de los significados que construimos y vemos discurrir (Adair \& Worth, 1972).

Esta fase crítica tiene además un sustrato epistémico, el que propone la crítica posmoderna al colonialismo de la antropología. Trinh T Minh-ha (1999) y Fátima Rony (1996) 
plantean el supuesto de que las películas etnográficas ayudan a humanizar los sujetos de investigación puesto que también es el momento para interpretar los diferentes puntos de vista de quienes intervienen en los registros, la adjudicación de significados que ya no están marcados sólo por las agendas teóricas y metodológicas de los investigadores: son imágenes co-producidas, dialogadas durante el trabajo de campo, que si bien propician nuevos significados para la academia, constituyen el lugar de sentido de las comunidades con las que trabajamos. Apoyándonos en Morphy \& Banks (1997) y Debray (1999) pensar la imagen de acuerdo a esta perspectiva plantea un análisis crítico de los determinantes de su construcción para entender sus impactos, ver polisémico, la mirada como un objeto producido socialmente donde se combinan las dimensiones de lo técnico, lo simbólico y lo político, lo histórico y lo geográfico. Con esto concluimos el trabajo y sale como resultado un documental (película) etnográfico, que después nos obliga a esta reflexión teórica, en la que también nosotros volvemos a mirar lo que hicimos y lo que aprendimos.
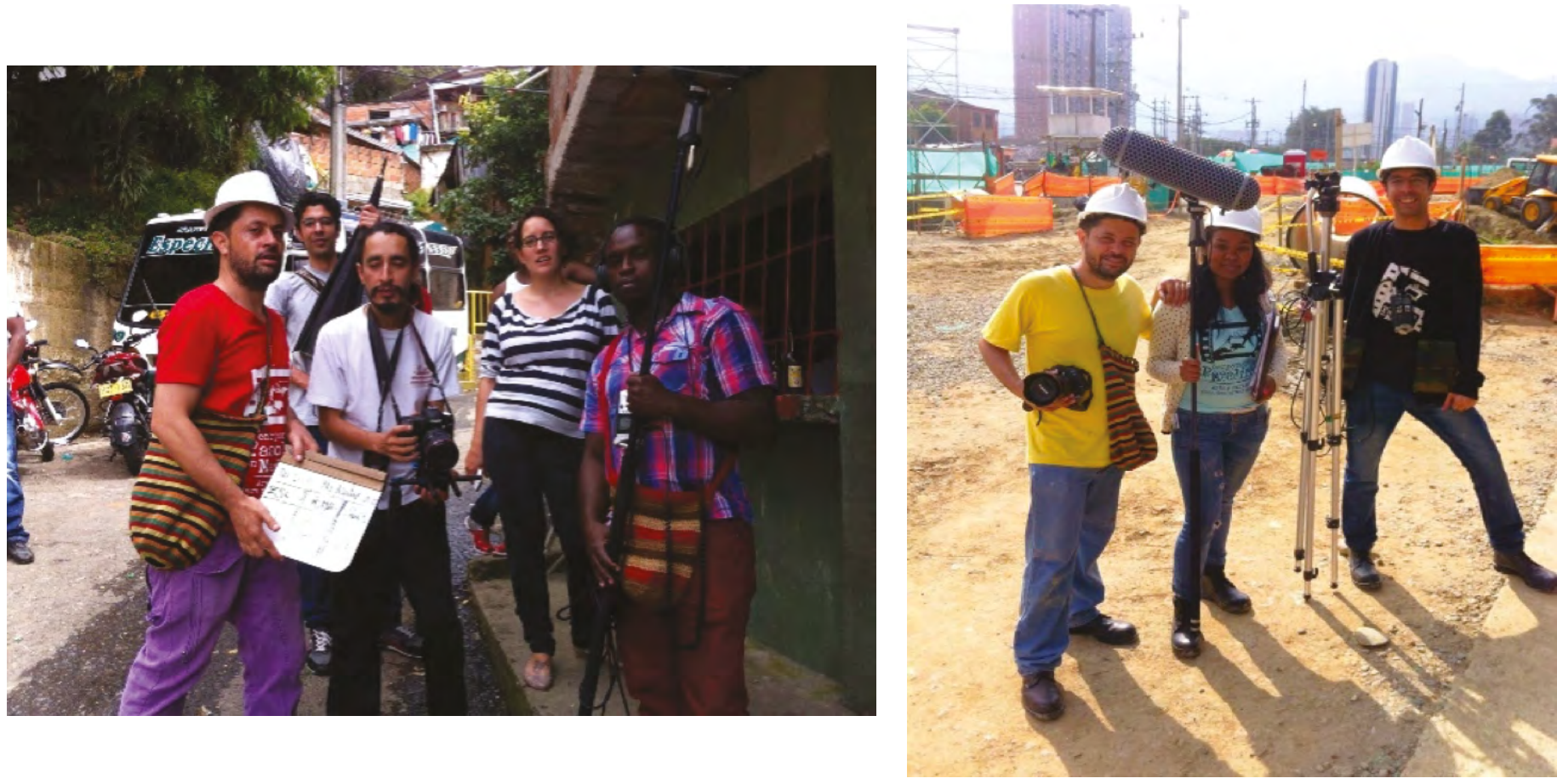

Fuente propia

\section{Conclusiones}

Una de las principales conclusiones se refiere a la biologización como argumento para el racismo y a la subordinación de una población a un tipo de trabajo. Se ubica en un lugar fijo a una población y se naturaliza, deshistoriza y descontextualiza su presencia allí, de tal manera que se vuelve habitual para todos. En este caso el oficio del pilero ha sido invisible, racializado, biologizado y deshistorizado. No se habla de su relación con la minería que es en este caso, el punto de anclaje de una tradición esclavista que sigue siendo importante en Chocó (y en otras regiones del país) y de la que se adaptaron paulatinamente elementos interpretativos para otros oficios. Este artículo, en el que se cuenta brevemente el proceso de elaboración de un documental etnográfico con los pileros y la descripción de algunas 
características de su oficio, procura mostrar algunos elementos de esta forma de racismo estructural, asociada al trabajo y a la manera de entender la existencia de un sujeto. Es central la explicación que hacen los pileros de su oficio y de cómo se sienten en él, y nos propone una lectura más amplia de lo que se juega un pilero en su día a día, implicando incluso sus deseos.

Si bien en la actualidad esto puede parecer un argumento obvio y generalizado en cierta comunidad académica especializada, todavía no lo es para la sociedad colombiana mayoritaria, en la que se han sedimentado las interpretaciones coloniales de los afro: parece entonces normal que los afro se ubiquen en esos oficios, no se cuestiona su posición ahí en relación con otros trabajos calificados, persiste la idea de que su desempeño en este trabajo tiene que ver con determinadas capacidades biológicas que además da el color de piel y se descalifica la reivindicación de derechos laborales lo que acrecienta la idea del servilismo para determinadas labores.

Descubrimos también que si bien la mayoría de pileros son afro, la excavación empieza a ser un oficio disputado por otros obreros, especialmente de Antioquia y la Costa Atlántica, a quienes los ingenieros contratan porque a su decir "son menos problemáticos que los morenos -hombres de papel-" (eufemismo para denotar mayor subordinación de los mestizos y el conocimiento de la ley de los afro) lo que ha favorecido la baja de precios, la dificultad de negociación de los afros, y la pauperización de esta labor que anteriormente era más rentable y ofrecía mayor libertad laboral al trabajador. Comprendemos este proceso en el marco del libre mercado y de formas de dominación en las que la negociación es asimétrica, asociada a la configuración de un ejército de reserva amplio en relación con la demanda y absorción de mano de obra disponible y a la individualización de las reivindicaciones. Esto pone en desventaja al trabajador quien tiene unas necesidades básicas que debe suplir y lo ubica en relación de dependencia con su trabajo, y en cambio dan ventaja al empleador, quien puede contratar y despedir sin mucha dificultad. Lo anterior fue evidente en las respuestas de los pileros al por qué no cambiar de trabajo, al detrimento del pago en la labor y a la dificultad de reclamar sus derechos laborales.

Encontramos una capacidad de resistencia reiterada a procesos de discriminación que fue comprobada en las reclamaciones laborales de muchos pileros, sus intentos de sindicalización, y sus insubordinaciones cotidianas expresadas especialmente en relación con los horarios. Resaltamos por su recurrencia, la búsqueda de los afros por legar un futuro diferente a sus hijos a través de la generación de oportunidades de profesionalización. Esto en todo caso sigue mostrando el racismo estructural que obliga a una generación entera al sacrificio para el desarrollo de la siguiente, para apenas un acceso simbólico del capital cultural mayoritario, sin que ello garantice la absorción adecuada del mercado de su fuerza de trabajo ni la transformación radical de las condiciones de exclusión, pues la mayoría de las veces esto implica procesos de adaptación, asimilación o blanqueamiento. También destacamos el tesón de Néstor, quien ratifica en el arte y la exploración estética la posibilidad de escape a las tensiones hegemónicas y deshumanizantes, que sin embargo no logra operar cambios estructurales en su forma de vida.

Con respecto a la reflexión metodológica para la antropología visual, subrayamos la elaboración de un trabajo colectivo que implicó debates personales, epistémicos e ideológicos. Esto fue un reto constante y demuestra la dificultad de articular consensos en equipos grandes e interdisciplinares cuando se trata de un solo producto final, y las funciones son asumidas de manera simultánea. Las diferentes percepciones sobre un mismo oficio generan conflictos: lo que para algunos es una experimentación teórico-práctica de antropólogos y sociólogos, para los realizadores audiovisuales es un error, carencia de estructura o parámetros estéticos mal concebidos. Los puntos de encuentro en el diálogo sobre esto son complejos y el mayor hallazgo de la experimentación es lograr productos 
diferentes que propician rupturas en la percepción de los participantes. Además de la discusión del equipo, se creó un diálogo con los pileros, quienes participaron de la construcción de la representación lograda en el documental etnográfico. Los pileros disfrutaron el resultado final y subrayaron que en él se destaque un oficio que ha sido invisible para buena parte de la población. No obstante, y en cuanto al video clip de la canción Mi linda chocoana, Néstor discrepa. Los referentes visuales que nos compartió y que serían su idea de un videoclip exitoso, se insertan en las representaciones dominantes y estereotipadas que exaltan la sexualidad y erotismo de una mujer exuberante y hombres que exponen símbolos de distinción como autos, piscinas, casas lujosas, entre otros. Al contrario, nuestro video clip muestra un paisaje barrial, una mujer chocoana hermosa pero cotidiana, y sitúa el video en referentes más cercanos. La imagen que el protagonista tiene de un videoclip no coincide con la que nosotros podíamos y queríamos proyectar.

Esto es importante debatirlo porque el principal acuerdo de ficción (pero también de la interacción y nuestra contrapartida a toda su confianza) es proponer que el protagonista busca a los etnógrafos y entonces como una especie de intercambio de saberes nosotros hacemos el videoclip a su música y él nos cuenta la historia de su oficio. Al final tenemos un documental al que es insertado el vídeo musical pero también creamos el vídeo musical como una pieza autónoma. Si partimos del presupuesto de que la construcción de los discursos antropológicos contemporáneos siguen implícitas de manera soterrada unas formas de colonialidad que tal vez hemos heredado de la Universidad, el espacio de la racionalidad moderna que más nos conecta con el pensamiento europeo o noratlántico, y desde donde se han construido discursos de poder y discriminación que marginalizan, no podíamos entonces construir una representación anclada en esta forma de estereotipo; construimos el guion del video clip con Néstor, pero el argumento estético del documental tenía que subvertir el del mercado (sexista, racista, heteronormativo, clasista), seguramente eso no lo ubica de la mejor manera en el mercado musical, pero propone otras formas de representación y reconstrucción identitaria, fin último del producto antropológico. De esta manera lo explicamos a Néstor, pues consideramos que las manifestaciones estéticas y artísticas, musicales, poéticas, visuales, abren paso a la producción de conocimiento científico y posicionan símbolos capaces de cuestionar el comercio simbólico dominante, "de devolver a los sujetos sociales el dominio de las falsas transcendencias que el desconocimiento crea y recrea sin cesar" (Bourdieu, 2002, p.61). Sin embargo, Néstor se sitúa en esas formas de representación que para nosotros son hegemónicas y hay allí un debate inconcluso que nos sitúa de nuevo en la necesidad del diálogo como experiencia creativa.

Las propuestas metodológicas de la etnografía audiovisual y colaborativa propician un diálogo, pero ello no quiere decir que el diálogo esté ausente de relaciones de poder y de referentes o significantes; no obstante permite ubicar esas relaciones en un mismo lugar para crear conversaciones que exponen y explicitan las asimetrías, lo que con otras metodologías puede quedar vedado. Además, la posibilidad de recrear la vida, de ficcionarla, nos permite situarnos críticamente frente a la realidad y pensar nuevos referentes producidos alrededor de estos diálogos.

\section{Referencias bibliográficas}

Adair, John, \& Worth, Sol. (1967). The navajo as filmmaker: a brief report of research in the cross-cultural aspects of film communication. American anthropologist 69(1).

Acosta, G \& Garcés A. (2013). "Prácticas de comunicación y apropiación de medios en colectivos de comunicación juveniles de Medellín." E,: Pereira, J.M. (editor) Cátedra Unesco de Comunicación. Encuentro Nacional de Investigación. Pontificia Universidad Javeriana. Bogotá. 
Acosta, G. \& C. Tapias. (2015). Comunicación en diálogo de saberes. Prácticas, saberes y subjetividades en dos escenarios: la academia y los colectivos de comunicación en Medellín. En Diálogos contemporáneos en América latina, Pardo Abril, N. G. \& L.E. Ospina Raigoza (comp.) UNC-IECO / ALED, Bogotá.

Arango, G. \& C. Perez. (2005). Atrapar lo invisible. Etnografía audiovisual y ficción. En Anagramas: Rumbos y sentidos de la comunicación, Vol. 6, №. 12, 2008, págs. 127-137.

Arango, G. (2012). El conflicto dramático en el conflicto social. En Nuevas antropologías Colombianas. Experiencias metodológicas. Espinosa, Góngora \& Tapias (Comp.) Ed Zenu. Montería.

Arroyo, L.M. (2007). La antropología dialógica en la historia de la filosofía. Themata, revista de Filosofía, Núm. 39, 2007

Ardévol, Elisenda. (1998). Por una antropología de la mirada; etnografía, representación y construcción de datos audiovisuales. Revista de dialectología y tradiciones populares, ISSN 0034-7981, Tomo 53, Cuaderno 2, 1998 págs. 217-240.

Bourdieu. P. (2002). Lección sobre la lección. Anagrama. Barcelona.

Carabalí, Alexis. (2007). "Los afronortecaucanos: de la autonomía a la miseria ¿un caso de doble reparación?", En: Claudia Mosquera y Luiz Barcelos (Eds.), Afro-reparaciones: Memorias de la esclavitud y justicia reparativa para negros, afrocolombianos y raizales, Universidad Nacional de Colombia, pp. 389-403. Bogotá.

Behar, Ruth. (2007). Ethnography in a time of blurred genres. Anthropology and Humanism32(2). University of California. 93. Translated Woman. Beacon Press Boston.

Behar, R. \& Deborah A. Gordon, Eds. (1995). Women Writing Culture. University of California Press, 457 pp. Berkeley.

Cataño, J.L. (2012). Narraciones e imágenes para una etnografía creativa. En: Nuevas antropologías Colombianas. Experiencias metodológicas. Espinosa, Góngora \& Tapias (Comp.) Ed Zenu. Montería.

Cadena, Marisol de la. (1998). Silent racism and intellectual superiority in Peru. Bulletin of Latin American Research 17(2).

Ceballos Montoya, César. (2011). Fotografía Pileros. Escuela Nacional Sindical, Medellín. Concurso los trabajos y los días. En línea: http://www.ens.org.co/index.shtml?s=$f \& m=d \& c m d \% 5 B 35 \% 5 D=c-1-6 a e a 9 f d a f 4501 c 42 d d 6 e 28 f f 78 c e a 17 e-2-\% 27 H o m-$ bres\%20trabajadores\%27\&v=6aea9fdaf4501c42dd6e28ff78cea17e

Clifford, James. (1999). Itinerarios Transculturales. Gedisa S.A. Barcelona.

Corbetta, Piergiorgio. (2007). Metodología y técnicas de investigación social. S.A. Mcgraw-Hill, Interamericana de España. Madrid.

Debray, Regis. (1999). Vida y muerte de la imagen. Paidós. Barcelona.

El Tiempo. (2014). Alcalde de Medellín enviara copias de estudio del Space a la Fiscalía. 3 de octubre de 2014, En línea: http://www.eltiempo.com/colombia/medellin/caida-del-edificio-space/14634263

Friedemann, Nina S. de. (1974). Minería del oro y descendencia: Güelmambí, Nariño. Revista Colombiana de Antropología 16: 9-51.

Friedemann, Nina S. de. \& Arocha, Jaime. (1986). De sol a sol. Génesis, transformación y presencia de los negros en Colombia. Bogotá. Planeta.

Guber, Rosana. (2005). El salvaje metropolitano. Paidós. Buenos Aires.

Grau Rebollo, Jorge. (2012). Antropología audiovisual: reflexiones teóricas. Alteridades, vol. 22, núm. 43, 2012, pp. 161-175. Universidad Autónoma Metropolitana Unidad Iztapalapa. Distrito Federal, México.

Luhmann, N. (1991). Sistemas sociales. Lineamientos para una teoría general. Alianza Editorial, Universidad Iberoamericana. México.

Marcus, G. \& D. Cushman. (1982). Etnographies as text. Annual Review of Anthropology, Vol. 11. (1982), pp. 25-69. 
Minh-ha, Trinh T. (1999). Cinema-Interval. Rutledge. New York.

Menéndez, Eduardo. (2001). Biologización y racismo en la vida cotidiana. Alteridades, vol. 11, núm. 21, enero-junio, 2001, pp. 5-39. Universidad Autónoma Metropolitana, Unidad Iztapalapa, Distrito Federal, México.

Morales, M.E. (2011). Barriendo la invisibilidad, ENS, Medellín.

Morphy, Howard \& Marcus, Banks. (1997). Re-thinking visual anthropology. Yale University Press. New Haven and London.

Pérez, Camilo. (2013). Images to disarm minds. An exploration of the "Pasolini en Medellín" Experience in Colombia. A thesis presented to the Communication and development Studies Program of Ohio University in partial fulfillment of the requirements for the degree Master of Arts. May, 2013.

Pérez, C.E. (2012). Después que se apaga la cámara. En: Nuevas antropologías Colombianas. Experiencias metodològicas. Espinosa, Góngora \& Tapias (Comp) Montería, Ed Zenu.

Reinoso Rodríguez, Guillermo. (2014). Los 'romperrocas' que se juegan la vida en las vías. El Tiempo, Medellín, 16 de septiembre de 2014, En línea: http://www.eltiempo.com/ colombia/otras-ciudades/obreros-que-cavan-pozos-en-colombia/14538977

Restrepo, Eduardo. (1996-1997). Invenciones antropológicas del negro. Revista Colombiana de Antropología, Volumen XXXIII, 1996 - 1997, Instituto Colombiano de Antropología, pp. 239 - 269, Bogotá.

Restrepo, Eduardo. (2007). Imágenes del "negro" y nociones de raza en Colombia a principios del siglo XX. En: Revista de Estudios Sociales No. 27, agosto de 2007, pp. 46 - 61, Bogotá.

Restrepo, Eduardo y Rojas, Axel. (2010). Inflexión decolonial: fuentes, conceptos y cuestionamientos. Popayán: Instituto de Estudios Sociales y Culturales Pensar, Universidad del Cauca.

Rony, Fatimah Tobing. (1996). The third eye: race, cinema, and ethnographic spectacle. Duke University Press.

Rouch, Jean. (1995). La cámara y los hombres. En: Ardévol, E. Pérez Tolón, L. (compiladores). Imagen y Cultura, Perspectivas del Cine Etnográfico. Granada: Diputación Provincial de Granada. pp. 95-121.

Sharp, William F. (1976). La rentabilidad de la esclavitud en el Choco, 1680 -1810. Anuario Colombiano de Historia Social y de la Cultura, [S.I.], n. 8, p. 19-46, jan. 1976. ISSN 2256-5647. Disponible en: <http://www.revistas.unal.edu.co/index.php/achsc/article/view/36323>. Fecha de acceso: 02 dec. 2016

Serna, S. (2011). Making a Living Out of the Imaginaries of Sea: Restaurants and Stereotypes on the Pacific Region in the City of Bogotá. Tabula Rasa, (14), 265-294.

Tapias, C. (3 de agosto de 2016). Ni libre ni asalariado. Obtenido de youtube: https://www. youtube.com/watch?v=sv8SRSCLOBY

Tapias, C. (2010). Fumando mañas. El sentido de la construcción social en un contexto de ilegalidad. Bogotá. Editorial Universidad del Rosario.

Taussig, Michel. (2002). Chamanismo, colonialismo y el hombre salvaje. Un estudio sobre el terror y la curación. Grupo Editorial Norma. Bogotá.

Wacquant, Loïc. (2007). Los condenados de la ciudad. Gueto, periferias y Estado. Buenos Aires: Siglo XXI.

Wade, Peter. (1997).Gente negra, Nación mestiza. Bogotá: Ediciones Uniandes, Siglo del Hombre editores, Instituto Colombiano de Antropología e Historia. 